\title{
LEGAL ANALYSIS OF COAL MINING IN EFFORTS TO MAINTAIN THE ENVIRONMENTAL SUSTAINABILITY
}

\author{
Iwan Irawan \\ Character Building Development Center, Bina Nusantara University \\ Jl. Kemanggisan Ilir III No. 45. Kemanggisan, Palmerah, Jakarta Barat, 11480 \\ iwan.irawan@ymail.com
}

\begin{abstract}
The goal of this article was to suggest the government to make the appropriate laws and policies in order to optimize the utilization of coal based on environmental sustainability. The research applied library research from several research results and the Act no. 4 of 2009. Data were analyzed qualitatively by the way of decomposition, connecting with the rules, and the legal experts' opinion. It can be concluded that investors are not optimal in managing and conserving the coal mining and the government has not standaridized the environmental management.
\end{abstract}

Keywords: environment, mining law, environmental restoration

\section{INTRODUCTION}

Mining activities in Indonesia now has a new legal framework issued by the Law of the Republic of Indonesia Number 4 - 2009 on Mineral and Coal Mining. Law on mineral and coal mining regulates the mining area, mining permit, and among others concerning mining business. The enactment of laws on mineral and coal mining new legislation replaces the old mining the Law of the Republic of Indonesia Number 11 of 1967. However, the release of laws on mineral and coal mining by the government not to change the old paradigm of the mining activities in Indonesia, where mining entrepreneur excavation quickly and sell it cheap.

Legislation and new coal mining have not touched the communities around the mine in order to increase the level of the economy and protect the environment around the mining area. Large scale mining has produced many problems not only to the surrounding community, but also a loss for the country, from PT Freeport Indonesia in Papua to Laverton Gold in Sumatra up to the mines in Bangka Belitung people to the banks of the rivers of Borneo. Foreign mining companies are treated exceptionally. All the minerals are only viewed as a commodity trading foreign exchange earned; do not have a destructive force. Indonesia mining industry did not increase class, only the provider of the raw materials, the economic subsidize the advanced countries through exports, and become a giant market of products processed in other countries, while in the environment around the mine damaged a large and increasing poor its (Press Releases JATAM-WALHI-ICEL-HuMA, 2005). Mining law also assessed but does not see the real conditions of mining in Indonesia which are tangled with the lack of capacity of the environment to continue to be mined (Press Releases JATAM-WALHI-ICEL-HuMA, 2005).

The data of Department of Forestry mentioned that at the beginning of 2009, the total area of degraded land in Indonesia reached 23 million hectares, while in the rather critical category reached 40 million hectares. To overcome and prevent the spread of degraded land has been conducted for Forest and Land Rehabilitation movement since 2003 and is expected to be able to restore the degraded land 
area of five million hectares until 2009. Until December 2008, the realization of the movement has reached three million hectares by spending state funds $\mathrm{Rp} 8.7$ trillion (Press Releases JATAMWALHI-ICEL-HuMA, 2005).

Environmentally sustainable development is one way that should be implemented by all mining operators in Indonesia. That is because one of the government's efforts for the welfare of its people is through the development of industry, especially the mining industry. According to NHT Siahaan, the presence of development as the needs of society and the nation. The presence of development may not be accounted for as severe damage to the ecological system that is happening now when the paradigm of development was seen as a relationship that is not contrary to the environmental issues. Development is interpreted as a goal and everything because it can finish the development trends of poverty, of underdevelopment and socio-economic problems of the other (Rosmini, 2008).

The closing of mining sites is an inevitable part but attracts less attention from the government. Lack of government attention is visible from the articles regulating the closure of mines in law on mineral and coal mining. The law on mineral and coal mining are not clearly spelling out procedures for closing the mine. The closing of the mine site became one of the most important issues in the current mining activity, particularly with put forward the concept of sustainable development (PB) or Sustainable Development initiated by WCED (1987) and encouraged by the Rio Declaration (Rio Earth Summit) in 1992.

Hopefully, this article can bring more information to the apparatus of the State concerned and aware that the Government should make the appropriate laws and policies in order to optimize the utilization of coal by encouraging environmentally sustainable development for the prosperity of the people. The government should increase the commitment in the implementation of environmental management standards to crack down on the employers and local government officials who violate the law and conduct environmental destruction.

\section{METHODS}

Data obtained from the results of research studies arranged document systematically to obtain a description of the Juridical Analysis of Coal Mining in Indonesia in keeping the environment under the Act no. 4 of 2009 on Mineral and Coal Mining and the Law no. 32 of 2009 on the environment. The data were analyzed qualitatively, by the way of decomposition, connecting with the rules applicable regulations, connect with the opinion of legal experts to draw conclusions made by the deductive approach (Wigyosoebroto, 1997).

In accordance with the characteristics of the formulation of the problem aimed to examine: "Juridical Analysis of Coal Mining in Caring for the Environment" uses descriptive analysis and qualitative nature writing methods. The author will elaborate on facts and theories that exist by way of literature studies and literature study (Library Research) through the primary legal materials, secondary and tertiary written or other legal materials. (Santoso, 2008).

Harmonization in the strict sense has meaning concerted effort to equalize the view, judgment or action steps in order to achieve goals or targets together because it is a form of joint venture then there are many parties involved in the achievement of shared goals or targets. The Output that should be harmonized is originated from two things. First, it is originated from the desire before stepping the parties who contribute to achieve the goals or targets along with the need to unify their understanding before taking action. Secondly, it is most likely to be originated from one or many different 
understandings to achieve the goals or targets together. The second possibility, if not immediately be harmonized will result in an attempt to hinder the achievement of goals or targets together. For the purposes of this paper, this study focuses on the issue of the possibility of a second.

The plurality of the legal system in Indonesia is very potential to pose a dilemma conditions. That potential, for example, occurs because there are so many different types of legislation. The regulations issued by various agencies, which together often do not coordinate well. The sort order of legislation had been made. The sort order is not always held onto forever because, in reality, there are various regulations which became effective although not in the sort order that is recognized by the positive law. All the challenges are certainly contributing to the condition of the Indonesian legal system dilemma.

Ministry of Energy and Mineral Resources (ESDM) has compiled a government regulation on the implementation of the activities of mining, mineral, and coal that are technically related to the Act (Act) No. 32 of 2009 on the Protection and Management of the Environment (PPLH). Inequality makes regulation so that the need for harmonization across sectors. Specifically, some of the clauses Mining Law were made with environment friendly; the preparation is very closely linked to the Law PPLH. The emergence of the Act PPLH impressive potential dilemma licensing conditions due to duplication of regulations that will be feared adverse mining companies.

Law no. 4 of 2009 on mining (as cited in Sarmadi, 2012), it is expected to encourage the implementation of the principles of good Minning and prioritize environmental practices; the existence of clear authority among governments; implementing empowerment of local/regional autonomy; applying fairness to all parties; restore the role of government (central and local) as a regulator; deciding the mining business as part of the spatial and apply the principles of conservation; applying the principles of openness with the auction system and integrate the management of data mining as well as the divestment of a foreign national for a national party. Actions taken in the field of mining covers the legal framework and administrative supervision as well as the potential problems of Law No. 32 of 2009 by Law No. 4 in 2009. The issuance of Law No. 32 of 2009 on the protection and management of the environment is a step forward in the effort to preserve the environment in sustainable development.

Conditions dilemma of legal product between Mining Law and the Law on the environment need to be harmonized so that both sides also need to do a joint review, to discuss the steps required in implementation in the field, for example by issuing government regulations which of course can accommodate interests of both sides party. Government and legislature must consider the public interest and community especially in minimizing conflict of interest of society in interpreting laws, especially the laws of Mining and Environment. In order to create the circumstances in the field between the public and employers have the same interpretation and there is no conflict of interest.

The impact caused by mining activities is not only felt by the public while the mine is still operating but until the mine closed. Damage to the forest environment has caused flooding in some mining areas; contaminated water sources are also the impact of mining activities. Traces of mine excavation were not reclaimed by the entrepreneur or investor who can interfere with the safety of surrounding communities. 
Table Some Coal Mining Company in East Kalimantan Suspected to Have Problems With the Environment

\begin{tabular}{|c|c|c|c|}
\hline No & Name of company / person & Issues & Law who breached \\
\hline 1 & $\begin{array}{l}\text { CV Tujuh Tujuh, coal, mining area of } \\
189.40 \text { hectares, located in Tanah } \\
\text { consists of Pit Rimbawan, Pit Gimun, } \\
\text { Pit Gunung Tangga, and Kal Tim. }\end{array}$ & $\begin{array}{l}\text { The company is not managing mine } \\
\text { water well. Mine water treatment } \\
\text { system is not adequate to treat water } \\
\text { runoff, even in some pit wastewater } \\
\text { dumped directly into public waters. The } \\
\text { Company does not undertake the } \\
\text { management of top soil so that the } \\
\text { concept of progressive rehabilitation } \\
\text { cannot be done. }\end{array}$ & $\begin{array}{l}\text { UUPPLH No. } 32 \text { of } 2009 \text {, } \\
\text { Article } 59 \text { PP } 201990 \text { on } \\
\text { Water Pollution Control. }\end{array}$ \\
\hline
\end{tabular}

2. KSU Mahatidana, coal, area 194 hectares, adjacent to the Citraland complex.

3. CV Bismillah Rest Kaltim, Coal, with an area of 100.30 hectares located in Kelurahan Lempake.

4. PT International Prima Coal, coal mining companies covering 3,238 hectares, in villages Handil Bakti and Bantuas with the production of 40,000 tons per month.

5. PT Energi Cahaya Industritama, coal, 1977.33 hectares area located in rawa makmur village, Handil Bakti, Bukuan, dan Bantuas.

6. Sukarya bin Harimat, coal, in the area Land of sea, South Kalimantan.

7. M Holdun dan M Amin, (Kota Muara Enim) and Hendri Chandra (Jakarta), coal regions.
The company does not have mine water treatment facilities. Mine wastewater directly goes into the environment.

The Company has not made the management of B3 waste and waste water well.

B3 waste management has still not done. Waste is mixed with domestic waste such as filter, cotton waste, and among others.

The company has not made the management of B3 waste and waste water well.

The company is personally doing illegal coal mining, thus damaging the environment. Verdict criminal case: 126/Pid.B/2003 / PN.PLH.

The company conducts illegal coal mining, thus damaging the environment. District Court panel verdict Muara Enim 8 months in prison and fined each subsidiary Rp 20 million and three months in prison.
UUPPLH No. 32 of 2009, Article 59, PP 201990 on Water Pollution Control.

UUPPLH No. 32 of 2009, Article 59, PP 201990 on Water Pollution Control.

UUPPLH No. 32 of 2009, Article 59, PP 201990 on Water Pollution Control.

UUPPLH No. 32 of 2009, Section 59; PP 201990 on Water Pollution Control.

Article 14 letter c jo. Article 31, paragraph 1 (a) Act No. 11 of 1967 on Principles of Mining.

Pasal 158 of Law No. 4 of 2009 on Mineral and Coal Mining (Minerba).

Development of the mining industry sector that is not followed by the development of environmentally sound would cause severe environmental damage, causing huge material losses. Evidence of environmental damage caused by mining activities is the opening of the forest as a coal mining site. Data issued by the Forestry Service of East Kalimantan said deforestation reached 350,000 hectares per year with a value equivalent to Rp. 66.6 trillion, as seen in the previous table.

The government through the Government Regulation No. 78 Year 2010 on Reclamation and Mine Closure provide clear rules regarding the steps to be taken by investors in carrying out reclamation and post-mining. The Government regulations provide guidance regarding the governance of reclamation and mine closure stages of exploration and mining operations phase, as seen in the previous table.

Investors must provide assurance reclamation (exploration phase and operation phase) and post-mining. Placement guarantee does not eliminate the obligation of investors to carry out reclamation. (Government Regulation No. 78 Year 2010 Article 32) Guarantees reclamation is 
intended to ensure the activities of mine reclamation as if the investor did not meet the criteria of the success of the ministers, governors, regents/mayors appropriate authority may specify the third to carry out reclamation activities partially or entirely.

According to the authors, entrepreneurs who run their business in accordance with environmental insight have extended the economic value somewhere. Mine site that is run without environmentally friendly will provide little benefit to the surrounding community, while the location of which dealt with environmentally sound will still provide benefits despite having no longer active.

Mining activities and the environment are two things that can not be separated; even there is a saying "There is no mining activity without destruction/pollution", although both of these cannot be separated because of their association (interdependency), the settings remain separate and even scattered in various regulations legislation. This is only natural because natural resource law and environmental law have different origins and even contradict each other. Natural resource law more focused on exploitation, while focusing on preservation of environmental law. The second law seems contradictory but always related to one another; such a relationship can be seen as two sides of a coin (Head, 1997: 56-57)

Cases related to mineral mining, the obligation of investors to the environment after the mining of coal can be seen in Law 4 Year 2009 on Mineral and Coal bind holders of IUP/Special Mining Business Permit (IUPK)/People's Mining Permit (IPR) for protecting the environment, through (Kusumo, 2009: 56). It is stated in article 95, that IUP and IUPK, shall make one of them comply with the tolerance limits of the carrying capacity of the environment. In article 96, it states as follows: In the application of the rules of good mining techniques, holders of IUP and IUPK shall carry one of which is the management and monitoring of mining environments, including reclamation and postmining. Article 99 states that each holder of IUP and IUPK shall submit a plan for reclamation and post-mining plans at the time of applying for a Production Operation IUP or Production Operation IUPK. In article 100, IUP and IUPK Holder shall provide a guarantee fund guarantee fund reclamation and post-mining.

Through the articles mentioned above, holders of IUP and IUPK have an obligation to plan for environmental protection since the exploration phase and carry it out at the stage of production to postmining operations in order to meet the success criteria for further reclamation and post-mining the area is returned to the government. To ensure that the reclamation and post-mining plans are implemented by the holder of IUP and IUPK, the companies are required to put the Post-Mining Reclamation Guarantee and Assurance.

The rule of law is not a guarantee of the implementation of environmental protection, but no less important is the legal awareness of all parties involved to comply with or enforce legislation (law enforcement) in mining and the environment. Mochtar Kusumaatmadja article entitled, "The legislation of environmental problems humans: Some thoughts and suggestions", presented at the National Seminar; "The management of the human environment in national development" in 1972. From above, it can be concluded that the law-making process concerning sustainable development, has not been fully integrated into economic development and social change as well as environmental considerations.

Modern mining activities that move and change thousands of tons of rock and ore per day are common. The topography of a region which is formed as a result of natural processes that take place during the hundreds of thousands, even millions of years can be changed and reformed by the mining equipment giant in just a short time. River flow direction can be changed in the process of opening the mine. Dry soil can be turned into a lake and emerges artificial hills formed from the mine effluent. It raises the loss did little good in the community as well as to the environment, for example, no longer grow vegetation, and the soil becomes barren. 
Such circumstances would give rise to a conflict of interests between the mining industry on the one hand and the effort to preserve the natural environment on the other. Although the problem is not a new problem, but the conflict of interest between mining with new environmental sustainability feels natural and even become a problem for the last thirty years. Environmental problems that may arise as a result of the mining business was diverse nature and shape (Ministry of Mines and Energy, 1995: 236).

First, the mining business in a relatively short period can change the shape and state of the ground surface topography (land impact), so that it can change the balance of the ecological system for the surrounding area. Secondly, mining can cause various disorders, among others; pollution due to dust and fumes that pollute the air and water, waste water, tailings, and mine effluent containing toxic substances. Also in the form of noise disturbance from a variety of heavy equipment, the sound of explosives and other disorders; Third, the mining is done without regard for safety and field geological conditions, can cause landslides, mine blasts, the collapse of the mine and earthquakes.

The mining technology capabilities has become better that the adverse effects of mining can be minimized. Environmental Management post-mining of PT. INCO in Sorowako and PT. Kaltim Prima Coal in Sangatta, East Kalimantan, through reclamation activities was very good, making the former mining areas become attractive and productive. Environmental recovery on some of the impacts caused by mining activities there is no legislation which states clearly and unequivocally especially regarding social responsibility in the form of fees or the cost of recovery.

The author argues that ideally, every pollution and environmental damage as well as the impact of both the physical and social environment is the responsibility of the mining business. Mining entrepreneurs have a lot to benefit from their natural resources mines, so there is no harm if the employer also did a part in protecting and preserving the environment around the mine.

The responsibilities are (1) providing special funds recovery, known as environmental funds and (2) providing the cost of restoring the environment delivered through royalties and fixed fees, given one of the elements the use of funds royalties and fixed contributions are recovery environment caused indirectly by the mining operations. Such practices, if observed, is very detrimental to the state, because royalties are part of the country or state revenues from the mining sector which should not be earmarked to fund environmental restoration fund, if it is used for environmental restoration may be incurred as a result of the recovery cost that is greater than the royalty itself.

\section{CONCLUSIONS}

Investors are not optimal in the management and conservation of the environment so that mining activities have resulted in environmental damage is severe enough since the government has not been optimal in enforcing environmental management standard that causes harm to the society and the state.

Coal mining industry should participate in the development of environmentally sound and actively participate in the management and conservation of the environment in order to provide welfare for the people and nation of Indonesia. The government must make the appropriate laws and policies in order to optimize the utilization of coal by encouraging environmentally sustainable development for the prosperity of the people. Also, the government should increase the commitment in the implementation of environmental management standards to crack down on the employers and local government officials who violate the law and conduct environmental destruction. Local and national media as well as non-governmental organizations should continue voicing the people's conscience and actively participate in supervising the implementation of coal mining and environmental preservation efforts. 


\section{REFERENCES}

Biro Lingkungan dan Teknologi DPE. (1998). Pelaksanaan Analisis Mengenai dampak Lingkungan (AMDAL) Kegiatan Pertambangan dan Energi. Jakarta

Departemen Pertambangan dan Energi. (1995). 50 Tahun Pertambangan dan Energi Dalam Pembangunan. Jakarta.

Haryono, W. S. (2007). Hukum Lingkungan. Universitas Islam Jakarta.

Head, J. W. (1997). Pengantar Umum Hukum Ekonomi. Jakarta: ELIPS.

Kusumo, H. A. (2009). Solusi Persoalan Lingkungan. Retrieved from www.majalahtambang.com.

Republik Indonesia. (1967). Undang-undang Tentang Pokok-Pokok Pertambangan (II), Undangundang No. 11 Tahun 1967 pasal 14. Sekretaris Kabinet Ampera. Jakarta

Republik Indonesia. (2009). Undang-undang tentang Pertambangan Mineral dan Batu Bara No. 4 Tahun 2009. Lembaran Negara Republik Indonesia Tahun 2009, No. 4. Menteri Hukum Dan Hak Asasi Manusia Republik Indonesia. Jakarta

Republik Indonesia. (2009). Undang-undang tentang perlindungan dan pengelolaan lingkungan hidup No. 32 Tahun 2009. Lembaran Negara Republik Indonesia 5059. Jakarta

Republik Indonesia. (2010). Peraturan Pemerintah Nomor 78 Tahun 2010 tentang Reklamasi dan Pascatambang. Lembaran Negara Republik Indonesia 5172. Jakarta

Rosmini. (2008). Pembangunan Industri Tambang Yang Berwawasan Lingkungan di Indonesia, Makalah Lingkungan Hidup. Universitas Mulawarman, Samarinda, Kalimantan Timur.

Santoso, M. J. (2008). Harmonisasi-peran-aparat-penegak-hukum. Retrieved from http://jodisantoso.blogspot.com/2008/07/

Sarmadi, A. S. (2012). Penerapan hukum berbasis hukum progresif pada pertambangan batu bara di Kalimantan Selatan. Masalah-Masalah Hukum, 41(1), 8-19.

Siaran Pers JATAM-WALHI-ICEL-HuMA. (2005). RUU Minerba Perparah Pemiskinan dan Kerusakan Lingkungan Akibar Pertambangan. Retrieved December 5, 2005 from http://www.icsd.or.id/indexeng.php?menu=show_news.php\&id=23\&lang=eng

Shidarta, Patlis, J. M., \& Kementerian Perencanaan Pembangunan Nasional/Badan Perencanaan Pembangunan Nasional (Indonesia). (2005). Menuju harmonisasi sistem hukum sebagai pilar pengelolaan wilayah pesisir Indonesia. Jakarta: Kementerian Perencanaan Pembangunan Nasional/Badan Perencanaan Pembangunan Nasional.

Wahyu, B. (1996). Metode Penelitian Hukum. Jakarta: Sinar Grafika.

Wigyosoebroto, S. (1977). Apakah sesungguhnya Penelitian itu, Kertas kerja, Universitas Erlangga, Surabaya Sumantoro, Aspek-aspek Pengembangan Dunia Usaha Indonesia, Bandung: Bina Cipta. 